\title{
A High Light on Lumpy Skin Disease in Iraq and The Middle East: A Review Article
}

\author{
H.B. AL-Sabaawy ${ }^{1}$; E.K AL-Hamdany ${ }^{1}$; A.A.AL-Sultan ${ }^{2}$; S.A.RDAM ${ }^{3}$ \\ ${ }^{1}$ Department of Pathology and Poultry Disease, Collage of Veterinary Medicine,University of Mosul, Iraq. \\ ${ }^{2}$ Department of Pathology and Poultry Disease, Collage of Veterinary Medicine,University of Tikrit, Iraq. \\ ${ }^{3}$ Department of pathology and poultry Disease, Collage of Veterinary Medicine,University of Baghdad, Iraq. \\ *Corresponding Author, H.B. AL-Sabaawy, E-Mail: hadeelbasim2006@gmail.com
}

\begin{abstract}
Lumpy skin disease is an infectious, eruptive disease that affected the different animal species, especially cattle . The causing virus is a member of the poxviridae family with Neethling strain. Transmission of the disease occurs by insect vectors and the most effective mean of control is by vaccination. The disease characterized by viremia, nodules on the skin, sitfast formation, weight loss, emaciation, and reduction in milk and meat production. During the past five years, lumpy skin disease has spread through the Middle East into the southeast, Europe, Russia, western Asia, and the Caucasus, nowadays LSD causing high morbidity and mortality rate in different epizootic sides; the morbidity and mortality of LSD range between 3-85 and 1-40\% this is due to genetic differences in lives stock resulting in varying susceptibility to the disease.
\end{abstract}

Keywords: Iraq, Lumpy Skin Disease, LSD, Neethling strain.

\section{Original Article: \\ DOI: HTTPS://DX.DOI.ORG/10.21608 IJAVS.2020.85608}

\section{Received : 21 March, 2020. \\ Accepted : 23 April, 2020. \\ Published in Apri, 2020.}

This is an open access article under the term of the Creative Commons Attribution $\quad 4.0 \quad$ (CC-BY) International License. To view a copy of this license, visit http://creativecommons.org/licenses/ by/4.0/

J. Appl. Vet. Sci., 5(2 ): $94-103$.

\section{INTRODUCTION}

LSD is a skin virus that belongs to the family of poxviridae and genus of Capripoxvirus (Greth, et al.,1992; OIE, 2014), it has nucleotide sequence, and it also encoded by (30) homologs of proteins of poxviral (Tulman, et al., 2001). It closely concerns antigenically to sheeppox and goat pox virus, but not complete its life cycle of replication in the non-ruminant host (Shen, et al., 2011), it is a vector -born disease which Transmitted by arthropods, blood-feeding insect including (stable flies and mosquitoes)(Carn and Kitching, 1995), the disease severity depended on the breed of cattle as well as capripoxvirus strain involved, dry season affects the spread of the virus and may cause an increase in the prevalence of disease (Gari et al., 2011).The skin lesion is experimentally produced in different types of animals like goats, sheep, impalas (Davies, 1991). In water buffaloes, there was a natural cause for this virus.

Lumpy skin disease leads to reduced milk production and sometimes death due to secondary bacterial infections, it also causes considerable economic losses owing to damage to hides, loss of milk production, mastitis, emaciation, mortality of up to $20 \%$ and disruption in the trade of cattle and their products. Infected cows may be suffering from temporary or permanent infertility (Irons et al., 2005; Tuppurainen and Oura, 2011). LSD was limited to countries in sub-Saharan Africa; from 1984 to 1988, the disease has distributed to the surrounding states, during 1988 in Egypt there was an outbreak, but the percent of morbidity was low than that for cattle (El-Nahas, et al., 2011; World Organisation for Animal Health,2017).

Cows are more severely affected with LSD virus (Sameea, et al., 2017)also, Jersey and Holstein Friesian are considered the high contagiousness and the virus causes significant economic losses of trading (Barnard et al., 1994 ; Tuppurainen, et al ., 2011), the disease has first detected during 1929 in Rhodesia then spread to a different area of the middle east (Tuppurainen and Oura,2012); during 2015 there was spread of the disease to Caucasus, Balkans and also to southeast Europe (Jameel, 2016). Iraq in 2014 has joined the ranks of LSD-affected countries (Al-Salihi, 2014; OIE, 2015). 


\section{H.B. AL-Sabaawy et al.}

\section{History of LSD.}

LSD, as an epidemic disease, was recorded in Zambia in 1929. It was considered as a score of insect bites hypersensitivity or even poisoning (Brenner,2006). Other cases have occurred between 1943 and 1945 in Zimbabwe, Botswana, and South Africa. LSD was first identified in east Africa during 1957and in Sudan in 1972 and west of Africa during 1974 and then spreading to Somalia during 1983; where about 8 Million of cattle is becoming ill and affected in 1989, the disease is still spread to different parts of the world until 1983 (Davies, 1991).

Nowadays the disease occurs in the most countries of Africa (Tuppurainen and Oura, 2012) between 1984 and 2009, the highest number of outbreaks of LSD were reported in middle east area (Oman) (House et al., 1990; Kumar, 2011; Tageldin et al., 2014), where the morbidity was about $(4.97 \%)$ and (13.6\%) (Ayelet et al., 2014). Also during this year the disease is reported In Iraq in August 2013 in Nineveh (Mosul), and Baghdad government then spread through all over the country (Table1) (Alsalihi and Hassan,2015); also in Iran and Turkey during October 2013 (Sherrilyn et al., 2013; Calistri et al.,2019).

\section{Etiology of LSD}

The causative agent of LSD is a member of the Poxviridae family, genus Capripoxvirus; it concerns antigenically to goat pox virus (GTPV) and sheep pox virus (SPPV) (Greth ,1992; Buller et al.,2005). The Capripoxvirus have oval profile shape that is a larger size than Orthopoxvirus so that this virus can grow on the different type of tissue, like chicken embryo fibroblasts, thyroid gland, rabbit kidney, skin and equine lungs, through primary isolation of virus the cytopathic effect may take up to eleven days accompanied to various kinds of serotype, except one types that are closely related serologically to poxvirus of goats and sheep and not easy to distinguish by routine technique (Tulman, et al., 2002; Katsoulos et al., 2018). The virus has many properties that make it resistant to physical and chemical factors, and it can stay inside the necrotic skin for more than one month (Bhanuprakash et al., 2006).

\section{Animal susceptibility}

The cattle and buffalo are the most species that become infected with LSD (Ali et al., 1990). A celibate clinical condition of Capri pox infection perhaps was described in Arabian Oryx(Greth , et al., 1992; Boshra et al.,2015). The clinical sign of the disease is starting within one week after entering the virus to the animal body (Ben-Gera et al.,2015). Many studies show that LSD is more severe in Friesian and crossbreed than native cow and more intense in young animals than the adult. It results in edema in the brisket and skin cellulite and grows of nodules, which facilitate the infestation of screwworm (Jameel,2016; Kate et al.,2003).

\section{Epidemiology and Transmission of LSD}

LSD virus does not spread easily among animals held in insect-proof pens, while contagion by contact can occur. The virus is still for an extended period as a skin lesion or inside the scabs so that it has a strong tropism for skin and dermis, and nodules appear on a different part of the animal body (nose, eye, rectum, genitalia) (Babiuk et al., 2008b). The virus is also excreted via lachrymal and nasal secretions, blood, saliva, milk, and semen of the infected animals may be sources of infection to other susceptible animals. Nodules that appear on the mucous membranes of the eyes, mouth, nose, udder, rectum, and genitalia also ulcerate and shed viruses, which serve as sources of infections (Babiuk $\boldsymbol{e t}$ al. 2008b).

In cattle, direct contact and ingestion of food are not considered as a common route of transmission even when viruses existing in lacrimal, nasal discharge and semen of infected animals. Although the transmission of the virus through semen has not been expounded experimentally, the virus can be transmitted through the semen of infected bulls and also by the milk of the lactating cow (Irons, et al., 2005; Osuagwuh et al., 2007) with a peak of lactation as well as in young animal that shows the more rate of clinical signs (Coetzer and Tuppurainen, 2004). Mechanical transmission of LSD mainly related to flying insects, the scourge of LSD occurs during the peak period of the effectiveness of the mosquitoes so that the warm and humid weather play essential roles in increasing morbidities (Ali et al., 2012; AU-IBAR, 2013).

The recent study shows that the virus of LSD has the ability to persist as transracial and transovarial in Rhipicephalus appendiculate and Rhipiecphalus decoloratus and as a mechanical transmission in Amblyomma hebraeum(Lubinga et al., 2013; Lubinga et al., 2014). The virus also has the ability to recover from Musca Glossina, Biomyia and other species that a potentially transmitted virus of LSD, the virus is detected in stomoxy calcitrans and Anopheles stephensi(Chihota et al., 2003), in Turkey, there was an outbreak due to the role of Culicoides species (biting midges) in the transmission of virus of LSD (Sevik and Dogan, 2017).

\section{The clinical sign of LSD}

LSD is considered as an acute infectious disease, The incubation period ranged 7-14 days that 
starting by fever then nodules ( $2-5 \mathrm{~cm}$ in diameter), enlargement of superficial lymph nodes (Elhaige $\boldsymbol{e t}$ al., 2017), the lesion may resolve rapidly, or they stay indurate and persisting as a hard lump (Wainwright $\boldsymbol{e t}$ al.,2013), location of this nodule is usually on the udder, muzzle, as well as in hairless area and perineum (Babiuk et al., 2008a). The lesion in the respiratory system leading to pneumonia, the presence of the typical skin nodules is strongly suggestive of LSD (Babiuk, et al., 2008b); it may appear in lung, larynx, trachea and also throughout the digestive tract, in the reproductive system the lesions may cause temporary or permanent sterility in cow and bulls (Constable $\boldsymbol{e t}$ al., 2017).

Infected cattle also may develop edematous swelling in their limbs and exhibit lameness(Abdulqa et al.,2016; Sprygin et al., 2018). Skin lesion, keratitis it may be bilateral or unilateral are also seen in the infected cow (Salib and Osman, 2011; Al-Salihi, 2014), the cutaneous lesion have the ability to persist as hard lumps, or it sequestrated so that it will be lead to a deep ulcer that filled with granulation tissue (WainWright et al., 2013). liver and kidney failures occur during LSDV infection, very young calves, lactating cows, and malnourished animals seem to develop more severe clinical signs that may be due to an impaired humoral immunity (Sevik et al., 2016). Other clinical signs include general malaise, fever, ocular and nasal discharge,inflammatory nodules (Constable et al., 2017), and a sudden decrease in milk production.

Morbidity and mortality in the recent Eurasian epidemic have been approximately $10 \%$ and $1 \%$, respectively(Body $\boldsymbol{e t}$ al.,2011). The severity of disease in the $10 \%$ of affected cattle in the herd can vary from mild to fatal, and some animals develop minimal numbers of nodules, which can be difficult to spot. In contrast, others develop innumerable nodules up to $3 \mathrm{~cm}$ in diameter. The factors determining which cattle develop mild and which developed a severe disease are unknown(El-Neweshy et al.,2013; Limon et al .2020).

\section{Economic losses caused by LSD}

LSD is categorized as a notifiable disease(OIE). Capri pox virus considers as worldwide impendence affected animals in Asia and Africa (king, et al., 2012; Babiuk et al., 2008a). LSD is regarded as a severe disease that is affecting on the product and leading to economic losses (Gezahegn et al., 2013), the disease has subsequent effects on cattle production including a decrease in feed intake, weight losses, abortion, infertility and decreases milk production (Hailu, 2015; Pritchett et al., 2006), and effect on international trade (Babiuk et al., 2008a; Abutarbush et al., 2013; EFSA, 2015).

The monetary implication of these casualties is significant to the flock owners, consumers and manufacturing sector which can process cattle products, losses of animals product is predestined when LSD is high between 40-60\% (Tuppurainen and Oura,2012; Gumbe, (2018).The disease disrupts the trade of cattle in endemic countries (Babiuk $\boldsymbol{e t}$ al., 2008a), during 2009 in Oman there were a high morbidity and mortality rates that occur in a farm population in Holstein cattle (Sherrylin et al., 2013). The disease can be transmitted from Africa to outside (Gari et al., 2011; Alemayehu et al.,2013).

\section{Pathogenesis and clinical observation of LSD}

Investigations on the pathogenesis of this disease are few (kenawy and Holoth, 2010). In general pathogenic mechanism includes implantation of the virus at the portal of entry, replication in the cells, spread to target organs, and diffuse into the surrounding environment. (Baron, et al.,1996; MaGavin and Zachry,2017). There have been few studies confirmed on the pathogenesis of LSD; in general, there is fever and viremia, followed by localization in the skin and development of nodules. Following Subcutaneous inoculation with LSDV, swelling at the site of inoculation developed 4 to 7 day, which is varying in size from 1 to $3 \mathrm{~cm}$ (Constable $\boldsymbol{e t}$ al., 2017). The regional lymph nodes are enlarged, then an eruption of these nodules usually follows 7 to 19 days.

LSDV is also demonstrated in saliva, semen, and skin nodules for several days after infection and development of fever. Viral replication occurs in fibroblasts, microphages, endothelial cells, and other cells in blood and lymph vessel walls cause vasculitis and lymphangitis in the affected areas. At the same time, infarction and thrombosis may result in severe cases( Al-salihi et al .,2015).there is vasculitis and lymphangitis also can be observed in diseased animals (Lindsy and Thomes, 2013), respiratory system involvement and manifestation are mainly due to stenosis of the trachea, with the formation of nodules that persist for a few weeks even to one month (Cfsph,2008).

\section{Gross and histopathological finding}

Grossly there is a nodule with different size, that become firm and raised but in some cases, they persist to fused into irregular plaques; photomicrograph( 1) Mulatu and Feyisa,2018, also there are necrotic lesions in different parts of the animal body (Tuppurainen et al., 2017), the regional lymph nodes are also enlarged they become congested 
and give a pyaemic focus in addition to cellulitis (Salib and Osman, 2011). The infected animal may show other clinical signs like tracheal stenosis, mastitis, as well as chronic orchitis (El-Neweshy $\boldsymbol{e t}$ al., 2013).

Histopathological changes of nodular skin lesions include hyperemia, edema severe hydropic degeneration, acanthosis and hyperkeratosis in the epidermis, granuloma, infiltration of the mononuclear cell, inclusion bodies and vacuolation. Hyperplasia also can be noticed, with the characteristic intracytoplasmic inclusion bodies could be seen in photomicrograph(2) (Ahmed and Dessouki,2013; Hasanain et al.,2019and Vaskovic et al.,2019), with eosinophilic cell and macrophage, lymphocytes, vasculitis due to tropism of the virus (Body et al., 2011). Coagulative necrosis and muscular damage can be seen during LSD infection (Sevik et al., 2016).

\section{Diagnosis}

Diagnosis of LSD is depended on morbidity, mortality rates also on histopathological features, laboratory investigations including biopsy material or crust through routine diagnostic techniques by using the electron microscope (Gari et al., 2008; Elkenway and Holoth, 2011), the detection of virus by using an electron microscope (OIE,2010); enzymelinked immune sorbent assay (Carn et al., 1994); polymerase chain reaction (Balinsky et al., 2008; Bowden et al., 2009; OIE, 2011), or virus neutralization test and ELISA methods (Heine $\boldsymbol{e t}$ al., 1999). At present, there are no test kits for LSD (Tuppurainen and Ourea,2012). The virus is not distinguished morphologically from cowpox (OIE,2010), the virus has the ability to propagate in caprine, ovine and bovine cell culture, especially lamb testis cell (Yacob et al., 2008).

\section{Differential diagnosis}

LSD can be confused with a group of diseases, including Bovine papular stomatitis (Parapoxvirus), Pseudo lumpy skin disease (caused by Bovine Herpesvirus 2), cutaneous tuberculosis, Pseudocowpox (Parapoxvirus), urticarial, Demodicosis (Demodex), insect or tick bites, Cowpox, Rinderpest, photosensitization, Dermatophilosis, Hypoderma bovis infection Besnoitiosis, Papillomatosis (Fibropapillomas, "warts") and Oncocercosis (Tuppurainen et al.,2005; Abutarbush, 2017).

\section{Treatment, control, and prevention}

There are no specific drugs used for the treatment of LDS. The only treatment available is supportive care of animals, including the use of antibiotics to prevent secondary bacterial skin infections and pneumonia, Intravenous fluid administration to avoid dehydration and treatment of skin lesions using wound care sprays. Also use Antiinflammatory drugs to keep up the appetite of animals. (Allen, et al.,2010; Neamat-Allah,2015 ; Babiuk ,2018b).

\section{Control of LSD}

One of the difficult but essential steps for LSD control is the vector control (Ticks \& Biting flies), where using repellents with insecticides can aid in the prevention of the disease. Also, the most effective means of control by using live homologous vaccines containing a Neethling-like strain of LSDV are recommended (Kate, et al., 2003; Ayelet et al., 2014; Gumbe, 2018), as well as the immune prophylaxis using immune stimulants (Brenner et al., 2006). Restricted animal movement and quarantine make a big difference in the disease prevalence. The calves of unvaccinated cow should be vaccinated before their age reach to 6 months (Lindsay and Thomas, 2013) the disposal of carcasses, insect control disinfection of premises and clearing slaughter out of affected animal of this can help in control measure (Irons, 2005; Gonstable et al., 2017).

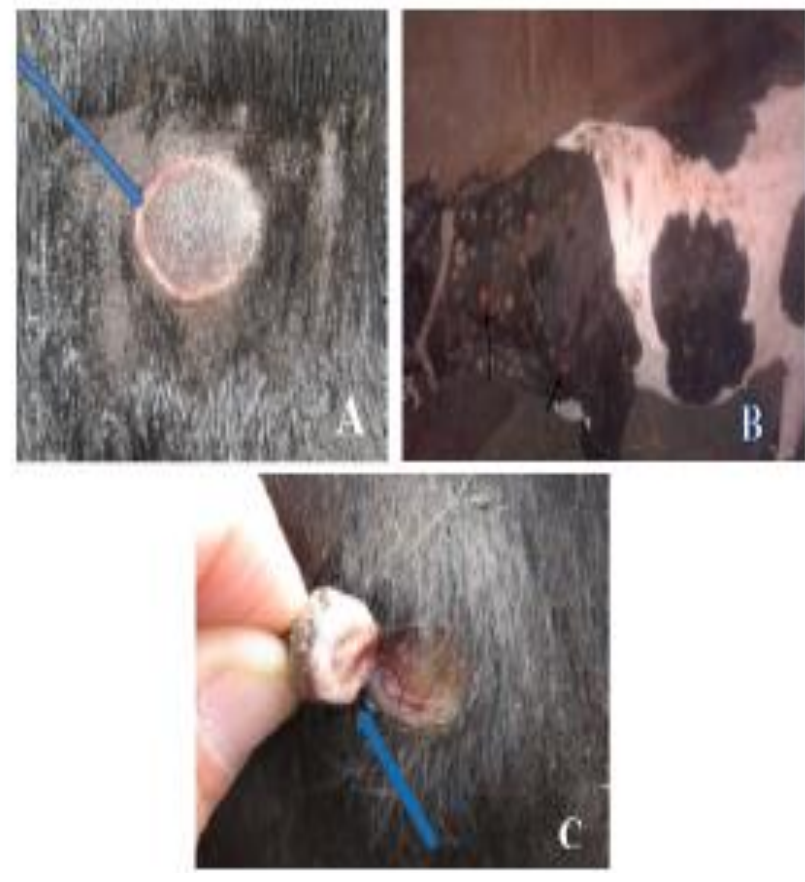

Photomicrograph 1: Shows Raised and separated narrow ring of hemorrhage (A ), ulcerated nodules(B) and sit fast like inverted conical necrosis zone (C) (Mulatu and Feyisa,2018). 
Tables1: The number of the outbreak of affected animals with lumpy skin disease in Iraq( Al-Salihi and Hassan,2015).

\begin{tabular}{|c|c|c|c|c|c|}
\hline $\begin{array}{c}\text { No. of } \\
\text { Outbreak }\end{array}$ & $\begin{array}{l}\text { Date of outbreak } \\
\text { and name of } \\
\text { governorate }\end{array}$ & $\begin{array}{l}\text { Species } \\
\text { of } \\
\text { animals }\end{array}$ & $\begin{array}{l}\text { No. of } \\
\text { animal in } \\
\text { the herd }\end{array}$ & $\begin{array}{l}\text { No. of } \\
\text { affected } \\
\text { animals }\end{array}$ & Summary of status of infected animals \\
\hline 1 & $\begin{array}{l}\text { End of August } \\
\text { 2013(Nineveh) }\end{array}$ & Cattle & 20 & 1 calf & $\begin{array}{l}\text { Skin nodules, sever } \\
\text { deterioration }\end{array}$ \\
\hline 2 & $\begin{array}{l}\text { End of August } \\
2013 \text { (Nineveh) }\end{array}$ & Cattle & 20 & 4 calf & $\begin{array}{l}\text { Skin nodules, weakness, nasal } \\
\text { discharge, reduce milk Production }\end{array}$ \\
\hline 3 & $\begin{array}{l}\text { End of August } \\
\text { Baghdad }\end{array}$ & Cattle & 70 & 15 cow & $\begin{array}{l}\text { Skin nodules, reduce milk } \\
\text { Production, mastitis }\end{array}$ \\
\hline 4 & $\begin{array}{l}\text { End of August } \\
\text { Baghdad }\end{array}$ & Cattle & 200 & 1 calf & $\begin{array}{l}\text { weakness, Skin nodules nasal } \\
\text { discharge }\end{array}$ \\
\hline 5 & $\begin{array}{l}\text { Early of Sept. } \\
2013 \text { Baghdad }\end{array}$ & Cattle & 16 & 1 calf & Skin lesion with severe deterioration \\
\hline 6 & $\begin{array}{l}\text { Early of Sept. } \\
2013 \text { Nineveh }\end{array}$ & Cattle & 3 & 1 cow & $\begin{array}{l}\text { Skin nodules, mastitis, mouth lesion } \\
\text { with severe respiratory sign }\end{array}$ \\
\hline 7 & $\begin{array}{l}\text { End of Sept. } \\
2013 \text { Baghdad }\end{array}$ & Cattle & 8 & $1 \mathrm{cow}$ & $\begin{array}{l}\text { Skin nodules, reduce milk production, } \\
\text { mastitis, mouth lesion with severe } \\
\text { respiratory sign }\end{array}$ \\
\hline 8 & $\begin{array}{l}\text { Early of October } \\
2013 \text { Nineveh }\end{array}$ & Cattle & 12 & 4 cow & $\begin{array}{l}\text { Skin lesion, mouth lesion, reduces milk } \\
\text { production, severe respiratory mouth } \\
\text { sign }\end{array}$ \\
\hline 9 & $\begin{array}{l}\text { Mid of October } \\
2013 \text { Baghdad }\end{array}$ & Cattle & 9 & 4 cow & $\begin{array}{l}\text { Skin lesion and nodules, reduce milk } \\
\text { production, severe mouth and } \\
\text { respiratory lesion }\end{array}$ \\
\hline
\end{tabular}





Photomicrograph 2: Skin lesion of cattle affected with LSDV show (a) acanthosis in the epidermis, (b) presence of vacuoles in the epidermis,(c) degenerative changes and spongiosis in the epidermis, (d) infiltration of inflammatory cell and hyperkeratosis in the epidermis,(e)intracytoplasmic inclusion bodies (arrow), (f) degenerative changes and intracytoplasmic inclusion bodies in the sebaceous gland cell (arrow) H \& E (Vaskovic et al .2019). 
A. GRETH, J. M. GOURREAU, M. VASSART, NGUYEN-BA-VY, M. WYERS, AND P. C. LEFEVRE, 1992. Capripoxvirus disease in an Arabian oryx (Oryx leucoryx) from Saudi Arabia," Journal of Wildlife Diseases, vol. 28, no. 2, pp. 295-300. ABDULQA H Y, RAHMAN H S, DYARY H O AND OTHMAN HH .2016. Lumpy Skin Disease .Reproductive Immunology, Vol.1 No.4:25.

ABUTARBUSH SM .2017. Lumpy Skin Disease (Knopvelsiekte, PseudoUrticaria, Neethling Virus Disease, Exanthema Nodularis Bovis). In: Bayry J (eds.) Emerging and Re-emerging Infectious Diseases of Livestock. Springer International Publishing, Gewerbestrasse 11, 6330 Cham, Switzerland, pp: 309326.

ABUTARBUSH SM, ABABNEH MM, AL ZOUBIL IG, AL SHEYAB OM, AL ZOUBI MG, ET AL. 2013. Lumpy Skin Disease in Jordan: Disease Emergence, Clinical Signs, Complications and Preliminaryassociated Economic Losses. Transbound Emerg Dis 62(5): 549-554.doi: 10.1111/tbed.12177.

AHMED AM AND DESSOUKI AA. 2013. Abattoir-Based Survey and Histopathological Findings of Lumpy Skin Disease in Cattle at Ismailia Abattoir.International Journal of Bioscience, Biochemistry and Bioinformatics. 3( 4): 372-375.

ALEMAYEHU, G., ZEWDE, G., AND ADMASSU, B. 2013. Risk assessments of lumpy skin diseases in the borena bull market chain and its implication for livelihoods and international trade. Trop. Anim. Health Prod. 45, 1153-1159. DOI: 10.1007/s11250-012-03409.

ALI AA, ESMAT M, ATTIA H, SELIM A, ABDELHUMID YM. 1990. Clinical and pathological studies on lumpy skin disease in Egypt. Vet Rec, Dec 1; 127(22), 549-55.

ALI H, ALI AA, ATTA MS, CEPICA A .2012. Common, emerging, vector-borne, and infrequent abortogenic virus infections of cattle. Transbound Emerg Dis. 2012 Feb;59(1):11-25.

ALLEN D.G., CONSTABLE P.D., DAVIES P.R., QUESENBERRY K.E., REEVES P.T., SHARMA J.M., ROGER K.W., SMITH M.A. AND TREADWELL T. 2010. Lumpy Skin Disease. Prevention and Treatment.The MERCK Veterinary Manual.(9th) Ed.PP; 792- 793.MERCK\&CO., INC., U.S.A.

AL-SALIHI KA .2014. Lumpy Skin disease: Review of literature. Mirror of Research in Veterinary Sciences and Animals (MRSVA). 3 (3), 6-23. DOI: 10.22428/mrvsa. 2307-8073.2014. 00332.

AU-IBAR .2013. African Union - Inter-African Bureau for Animal Resources: lumpy skin disease. Selected content from the Animal Health and Production Compendium.

AYELET G., HAFTU R, JEMBERIE S, BELAY A, GELAYE E, SIBHAT B, SKJERVE E AND ASMARE K. 2014. Lumpy skin disease in cattle in central Ethiopia: outbreak investigation and isolation and molecular detection of the virus. Rev Sci Tech 33 (3), 877-887.

B. J. BARNARD, E. MUNZ, K. DUMBELL, AND L. PROZESKY, 1994. Lumpy skin disease," in Infectious Diseases of Livestock with special reference to Southern Africa, J. A. W. Coetzer, G. R. Thomson, and R. C. Tustin, Eds., vol. 1, pp. 604-612, Oxford UniversityPress, Oxford, UK, BABIUK S .2018b.treatment of lumpy skin disease :in lumpy skin disease ,springer,Cham, pp 81-18.

BABIUK S, BOWDEN TR, BOYLE DB, WALL ACE DB, KITCHING RP .2008a.Capripoxvi ruses: An Emerging Worldwide Threat to Sheep, goats and cattle Trans bound Emerg Dis 55: 263-572.

BALINSKY CA, DELHON G, SMOLIGA G, PRARAT M, FRENCH RA, GEARY SJ, ROCK DL, RODRIGUEZ LL. 2008. Rapid preclinical detection of sheep pox virus by a real-time PCR assay. Journal of Clinical Microbiology, 46(2):438-442.

BARON S., FONS M, AND ALBRECHT T, 1996. Viral pathogenesis, "Medical Microbiology, S. Baron, Ed., chapter 45, University ofTexas Medical Branch at Galveston, Galveston, Tex, USA, $4^{\text {th }}$ edition .

BEN-GERA J, KLEMENT E, KHINICH E, STRAM Y, SHPIGEL NY . 2015. Comparison of the efficacy of Neethling lumpy skin disease virus and x10RM65 sheep-pox live attenuated vaccines for the prevention of lumpy skin disease - The results of a randomized controlled field study. J. Vaccine. Sep11;33(38): 4837-42 doi10.1016/j.vaccine.2015.07.071.

BODY M, PAL SINGH K, HAMMID HUSSAIN M, AL-RAWAHI A, AL-MAAWALI M, ET AL. 2011. Clinico-Histopathological Findings and PCR Based Diagnosis of Lumpy Skin Disease in the Sultanate of Oman. Pakistan Vet J 32: 206-210.

BOSHRA H, TRUONG T, NFON C, BOWDEN TR, GERDTS V, TIKOO S, BABIUK LA, KARA P, MATHER A, WALLACE DB, BABIUK S.2015.A lumpy skin disease virus deficient of an IL10 gene homologue provides protective immunity against virulent capripoxvirus challenge in sheep and goats Antiviral Res.;123:39-49. DOI: 10.1016/j.antiviral.

BOWDEN TR, COUPAR BE, BABIUK SL, WHITE JR, BOYD V, DUCH CJ, SHIELL BJ, UEDA N, PARKYN GR, COPPS JS, BOYLE DB. 2009. Detection of antibodies specific for sheep pox and goat poxviruses using recombinant Capri pox virus antigens in an indirect enzyme-linked immunosorbent assay. Journal of Virological Methods, 161(1):19-29.

BRENNER J, HAIMOVITZ M, ORON E, STRAM Y, FRIDGUT O, BUMBAROV V, KUZNETZOVA L, OVED Z, WASERMAN A, GARAZZI S, PERL S, LAHAV D, EDERY N. AND YADIN H. .2006. Lumpy skin disease (LSD) in a large dairy herd in Israel.Isr. J. vet. Med. 61: 73-77.

BULLER R.M., ARIF B. M., BLACK D.N., 2005. Family poxviridae," in Virus Taxonomy: Classification and Nomenclature of Viruses.Eighth Report of the International Committee on Taxonomy of Viruses, C.M. Fauquet, M. A.Mayo, J.Maniloff, U.Desselberger, and L. A. Ball, Eds., pp. 117-133, Elsevier Academic Press, SanDiego, Calif, USA.

CALISTRI P, DECLERCQ K, GUBBINS S, KLEMENT E, STEGEMAN A, NAS ABRAHANTES J, ANTONIOU S, BROGLIA A AND GOGIN A.2019. Lumpy skin disease, Data collection and analysis. 
European Food Safety Authority (EFSA) Journal;17(3): 5638.

CARN VM, KITCHING RP, HAMMOND JM, CHAND P, ANDERSON J, BLACK DN. 1994. Use of a recombinant antigen in an indirect ELISA for detecting bovine antibody to capripoxvirus. Journal of Virological Methods, 49(3):285-294.

CARN VM1, KITCHING RP .1995. An investigation of possible routes of transmission of lumpy skin disease virus (Neethling). Epidemiol Infect.;114(1):219-26.

Cfsph .2008. The Central for Food Security and Public Health, Iowa State University, College of Veterinary Medicine.

CHIHOTA CM, RENNIE LF, KITCHING RP, MELLOR PS .2003. Attempted mechanical transmission of lumpy skin disease virus by biting insects. Med Vet Entomol. 17(3): 294-300.

COETZER JAW, TUPPURAINEN E 2005. Lumpy skin disease, infectious diseases of livestock, edited by Coetzer JAW, Tustin RC. Cape Town: Oxford University Press Southern Africa, 2: 1268-1276.

CONSTABLE PD, HINCHCLI, 26- KW, DONE SH, GRUNDBERG W .2017. Veterinary Medicine: A Textbook of the Diseases of Cattle, Horses, Sheep, Pigs, and Goats. 11th ed. Elsevier, UK, p: 1591.

DAVIES FG. 1991 .A Lumpy skin disease, an African Capri pox virus disease of cattle. Br. Vet. J., 147:489-502.

EFSA .2015. European Food Safety Authority.Scientific Opinion on Lumpy Skin Disease.EFSA Panel on Animal Health and Welfare (AHAW). EFSA Journal vol 13: number1, article 3986.

ELHAIG MM, SELIM A, MAHMOUD M .2017. Lumpy skin disease in cattle: Frequency of occurrence in a dairy farm and a preliminary assessment of its possible impact on Egyptian aloes. Onderstepoort $\mathrm{J}$ Vet Res 28;84(1):e1-e6. DOI: 10.4102/ojvr.v84i1.1393.

EL-KENAWY AA, EL-THOLOTH MS .2011. LSD Virus identification in different Tissues of Naturally Infected cattle and Chorioallantoic Membrane of Embryonated Chicken Eggs Using Immune fluorescence Immunovperoxidase Techniques and Polymerase Chain reaction Int J. Virol 7(4): 158-166.

EL-KENAWY AA, HOLOTH, MS .2010. Sequence analysis of attachment gene of lumpy skin disease and sheep poxviruses. Virol Sin 25(6): 409-416.doi: 10.1007/s 12250-010-3150-0.

EL-NAHAS EM, HABBA AS, EL-BAGOURY GF, RADWAN EI .2011. Isolation and Identification of Lumpy Skin Disease Virus from Naturally Infected Buffaloes at Kaluobia, Egypt. Global Veterinaria 7 (3): 234-237.

EL-NEWESHY M.S., EL-SHEMEY T.M AND YOUSSEF S. A. 2013. Pathologic and Immunohistochemical Findings of Natural Lumpy Skin Disease in Egyptian Cattle. Pak Vet J, 33(1): 60-64.

F. A. SALIB AND A. H. OSMAN, "Incidence of lumpy skin disease among Egyptian cattle in Giza Governorate, Egypt," VeterinaryWorld, vol. 4, no. 4, pp. 162-167,. 2011.

GARI G1, BONNET P, ROGER F, WARET-SZKUTA A. 2011. Epidemiological aspects and financial impact of lumpy skin disease in Ethiopia.Prev Vet Med. 2011
Dec

$15 ; 102(4): 274-83$.

DOI:10.1016/j.prevetmed.2011.07.003

GARI GF， BITEAU-COROLLER C, LEGOFF P, ROGER CF .2008. Evaluation of Indirect Fluorescent Antibody Test (IFAT) for the Diagnosis and Screening of Lumpy Skin Disease Using Bayesian Method. Vet Microbiol 129(3-4): 269-280.

GEZAHEGN ALEMAYEHU, GIRMA ZEWDE AND BERHANU ADMASSU. 2013. Risk assessments of lumpy skin diseases in Borena bull market chain and its implication for livelihoods and international trade. Trop Anim Health Prod. 45(5):1153-1159. DOI 10.1007/s11250-012-0340-9.

GRETH A, Goudreau JM, Vassart M, Nguyen-BaVy, Wyers M, Lefevre PC. 1992. Capripoxvirus disease in an Arabian Oryx (Oryx leucoryx) from Saudi Arabia. Journal of Wildlife Diseases, 28(2):295300 .

GUMBE A A F . 2018. Review of lumpy skin disease and its economic impacts in Ethiopia.Dairy Vet Anim Res. 2018;7(2):39-46. DOI: $10.15406 / j d v a r .2018 .07 .00187$.

HAILU B. 2015. Economic Importance and Control Techniques of Lumpy Skin Diseases. Animal and Veterinary Sciences Science Publishing Group;.;3(2):58. doi.org/10.11648/j.avs.20150302.15

HASANAIN A. J. GHARBAN,1 SATTAR J. J. ALSHAELI, HAMS H. H. AL-FATTLI, AND MUTHANNA N. K. ALTAEE4 . 2019. Molecular and histopathological confirmation of clinically diagnosed lumpy skin disease in cattle, Baghdad Province of Iraq.Vet World.12(11): 18261832. doi: 10.14202/vetworld.2019.1826-1832.

HEINE HG, STEVENS MP, FOORD AJ, BOYLE DB. 1999. A Capri poxvirus detection PCR and antibody ELISA based on the major antigen P32, the homolog of the vaccinia virus H3L gene. Journal of Immunological Methods, 227(1/2):187-196.

HOUSE JA' WILSON TM, EL NAKASHLY S, KARIM IA, ISMAIL I, EL DANAF N, MOUSSA AM, AYOUB NN. 1990. The isolation of lumpy skin disease virus and bovine herpesvirus-4 from cattle in Egypt. J Vet Diagn Invest, 2(2):111-115; 15.

IRONS PC, TUPPURAINEN ESM, VENTER EH. 2005. Excretion of lumpy skin disease virus in bull semen. Theriogenology, 63(5):1290-1297.

J. C. LUBINGA, E. S. M. TUPPURAINEN, J. A. W. COETZER, W. HSTOLTSZ, AND E. H. VENTER, 2014. Evidence of lumpy skin disease virus over-wintering by transstadial persistence in Amblyommahebraeum and transovarial persistence in Rhipicephalus decoloratuticks, Experimental and Applied Acarology, vol. 62, no. 1, pp. 77-90.

JAMEEL G H. Determination of complications decreases the risk factor in cattle infected by lumpy skin disease virus in Diyala province, Iraq. 2016. International Journal of Micro Biology, Genetics, and Monocular Biology Research Vol.2, No.1, pp.1-9.

KATE BABIUK S, BOWDEN T, BOYLE D, WALLACE D, KITCHING RP .2008b. Capripox viruses: an emerging worldwide threat to sheep goats and cattle. Trans bound Emerg Dis 55: 263-272. 
KATSOULOS PD, CHAINTOUTIS SC, DOVAS CI, POLIZOPOULOU ZS, BRELLOU GD, AGIANNIOTAKI EI, TASIOUDI KE, CHONDROKOUKI E, PAPADOPOULOS O, KARATZIAS H, BOSCOS C. 2018. Investigation on the incidence of adverse reactions, viremia and haematological changes following field immunization of cattle using a live attenuated vaccine against lumpy skin disease.Transbound Emerg Dis. Feb;65(1):174185. DOI: $10.1111 /$ tbed.12646.

KING AM, ADAMS MJ, CARSTENS EB, EFKOWITZ EJ .2012. Virus Taxonomy. Classification and Nomenclature of Viruses. Ninth Report of the International Committee on Taxonomy of Viruses, pp: 289-307.

KUMAR S M., 2011. An Outbreak of Lumpy Skin Disease in a Holstein Dairy Herd in Oman: A Clinical Report. Asian Journal of Animal and Veterinary Advances, 6, 851-859.

LIMON G, GAMAWA A A., AHMED A I, LYONS N A. AND BEARD PM .2020. Epidemiological Characteristics and Economic Impact of Lumpy Skin Disease, Sheeppox, and Goatpox Among Subsistence Farmers in Northeast Nigeria. Front. Vet. Sci., 29 January | https://doi.org/10.3389/fvets.2020.00008.

LINDSAY S. AND THOMAS E. 2013. Lumpy-skin disease: A disease of socio-economic importance. Agriculture, Forestry, and Fisheries P.16.www.daff.gov.za/publications.

LUBINGA JC, TUPPURAINE ES, STOLTSZ WH, EBERSOHN K, COETZER JA, ET AL. 2013. Detection of lumpy skin disease virus in saliva of ticks fed on lumpy skin disease virus-infected cattle. Exp Appl Acarol Sep;61(1):129-38. DOI: 10.1007/s10493013-9679-5.

MAGAVIN MD, ZACHRY, JF. 2017.Pathological basis of veterinary disease .6th ed.New York: Mosby Elsevier; DOI 10.1016lb978-0-323-35775-3.00026-6.

MULATU E AND FEYSIA A.2008.Review:Lumpy skin disease .J Vet Sci Technol.(9:3)1-8.Doi:10.4172\21577579.1000535 .

NEAMATALLAH ANF. 2015. Immunological,hematologic al, biochemical, and histopathological studies on cows naturally infected with lumpy skin disease. Vet World. 8(9):1131-1136. doi: 10.14202.

OIE .2011. Lumpy Skin Disease. Terrestrial Animal Ethiopian Veterinary associations (EVA). Addis Health Code. OIE, Paris.

OIE .2014. Report on Immediate Notification of LSDV in $\begin{array}{llll}\text { Azerbaijan } & 7 & \text { July } & \text { 2014. Available }\end{array}$ athttp://www.oie.int/wahis 2/public/wahid.php/Reviewr eport/Review?page refer=MapFullEventReport\&reporti $\mathrm{d}=15632$.

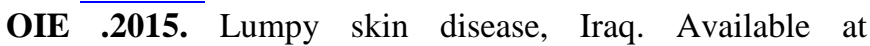
www.oie.int/wahis_2/public/wahid.php/Reviewreport/R eview?reportid=14444\&newlang=en (accessed January 30, 2015).

OIE TERRESTRIAL MANUAL .2010. Lumpy Skin Disease, Chapter 2.4.14. Available at: http://www.oie.int/fileadmin/Home/eng/Health_standa rds/tahm/2.04.14_LSD.pdf (accessed May 14, 2015).
OSUAGWUH U. I., BAGLA V., VENTER E. H., ANNANDALE C. H. AND IRONS P. C. 2007. Absence of lumpy skin disease virus in semen of vaccinated bulls following vaccination and subsequent experimental infection.Vaccine. 25(12): 2238-2243.

PRITCHETT, J, THILMANY, D. AND JOHNSON, K. 2006. UnderstandingBroader Economic Effects of Livestock Insurance and Health Management: Impacts of Disease Outbreaks on Allied Industries. The Economics of Livestock Disease Insurance 17:207221.

SALIHI KA AND HASSAN IQ . 2015. Lumby skin diseases in Iraq: study of disease emergence.Transboundary and emerging diseases 62(5) DOI:10.1111 tbed .12386.

SAMEEA YOUSEFI P, MARDANI K, DALIRNAGHADEH B, JAL IL ZADEH-AMIN G. 2017. Epidemiological Study of Lumpy Skin Disease Outbreaks in North-western Iran. Transbound Emerg Dis. 64(6):1782-1789. DOI: 10.1111/tbed.12565.

SEVIK M, AVCI O, DOLAN M AND BARJG ENCE .2016. Serum Biochemistry of Lumpy Skin Disease Virus-Infected Cattle. BioMed Research International Volume .2016. DOI: 10.1155/2016/6257984, 6 pages.

SEVIK M, DOGAN M .2017. Epidemiological and Molecular Studies on Lumpy Skin Disease Outbreaks in Turkey during 2014-2015. Transbound Emerg Dis 64(6): 1268-1279.doi: 10.1111/tbed.12501.

SHEN YJ, SHEPHARD E, DOUGLASS N, JOHNSTON N, ADAMS C. 2011. A novel candidate HIV vaccine vector based on the replication-deficient Capripoxvirus, Lumpy skin disease virus (LSDV). Virol J 8: 265.

SHERRYLIN WAINWRIGHT, AHMED EL IDRISSI, RAFFAELE MATTIOLI, MARKOS TIBBO, FELIX NJEUMI, ERAN RAIZMAN. 2013. The emergence of lumpy skin disease in the Eastern Mediterranean Basin countries. Empress watch. Volume 29 NOVEMBER 2013. (C) FAO, 2013.

SPRYGIN A, BABIN Y, PESTOVA Y, KONONOVA S, WALLACE DB, VAN SCHALKWYK A, BYADOVSKAYA O, DIEV V, LOZOVOY D, KONONOV A.PLOS.2018. Analysis and insights into recombination signals in lumpy skin disease virus recovered in the field. PLoS ONE 13(12): e0207480. https://doi.org/10.1371/journal.pone.0207480.

TAGELDIN MOHAMED HASSAN \& WALLACE DAVID BRIAN \& GERDES GERTRUIDA HERMANN \& PUTTERILL JOHN FRASER \& GREYLING ROELF RUDOLPH \& PHOSIWA MAANDA NOAXE \& AL BUSAIDY RASHIED MOHAMMED \& AL ISMAAILY SULTAN ISSA. 2014. Lumpy skin disease of cattle: an emerging problem in the Sultanate of Oman. Trop Anim Health Prod 46:241-246. DOI 10.1007/s11250-013-0483-3.

TULMAN CL, AFONSO ZLU, ZSAK L, KUTISH GF, ROCK DL .2001. Genome of Lumpy Skin Disease Virus. J Virol 75: 7122-7130. 
TULMAN CL, AFONSO ZLU, ZSAK L, KUTISH GF, ROCK DL .2002. The genomes of sheep pox and goat poxviruses. J Virol 76:(12); 6054-6061.

TUPPURAINEN E.S.M. \& OURA C.A.L. 2012. - Review: lumpy skin disease: an emerging threat to Europe, the Middle East, and Asia. Transbound. emerg. Dis., 59, 40-48.

TUPPURAINEN ES, ALEXANDROV T, BELTRANALCRUDO D .2017. Lumpy skin disease field manual - A manual for veterinarians. FAO Animal Production and Health Manual 20, united nation.pp: 1-60.

TUPPURAINEN ES, COETZER JA, VENTER EH .2005. The detection of lumpy skin disease virus in samples of experimentally infected cattle using different diagnostic techniques. Onderstepoort J Vet Res 72(2): 153-164.

TUPPURAINEN ES, STOLTZ WH, TROSKIE $M^{2}$, WALLACE DB, OURA CA, MELLOR PS, COETZER JA, VENTER EH. .2011. A Potential Role for Ixodid (Hard) Tick Vectors in the Transmission of Lumpy Skin Disease Virus in Cattle. Transbound Emerg Dis 58: 93-104.

V. BHANUPRAKASH.B.K.INDRANI M.HOSAMANIA R.K.SINGH. 2006. Comparative Immunology, Microbiology, and Infectious Diseases, Volume 29, Issue 1Pages 27-60.

VASCOVIC NIKOLA,PEBELJAK ZORAN,VIANOVIC DEJAN,SKLER MILANKA, MATOVIC KAZIMIR, ANICIC MILAN AND MARINKOVIC DARKO.2019. Moephological characteristics of skin lesions in cattle naturally infected with lumpy skin disease virus in Serbia .Acta Veterinaria-Beogard ,69(4),369-378.Doi:10.24781 acve -2019-0031.

WAINWRIGHT SH, EL IDRISSI A, MATTIOLIO R, TIBBO M, NJEUMI F, ET AL. 2013. Emergence of lumpy skin disease in the Eastern Mediterranean Basin countries. Emp Watch 29: 2.
WORLD ORGANISATION FOR ANIMAL HEALTH .2017. Manual of Diagnostic Tests and Vaccines for Terrestrial Animals. OIE, Paris. http://www.oie.int/en/international-standardsetting/terrestrialmanual/access-online/

YACOB HB, NESANETANDDINKA A .2008. Part II: Prevalence of major skin diseases in cattle, sheep and goats at Adama Veterinary Clinic, Oromia regional state, Ethiopia. Rev Med Vet 159(8-9): 455-461.

How to cite this article:

H.B. AL-Sabaawy; E.K AL-Hamdany; A.A.AL-Sultan; and S.A., RDAM· 2020. A High Light On Lumpy Skin Disease In Iraq And The Middle East: A Review Article. Journal Of Applied Veterinary Sciences, 5(2): 94 - 103.

DOI: HTTPS://DX.DOI.ORG/10.21608/JAVS.2020.85608 